\title{
$\mathrm{SNS}$ 서비스유형을 조절변수로 한 사용자만족도의 구조모형
}

\author{
윤상훈* · 김근형** · 오성렬***
}

I. 서론

П. 이론적 배경 및 선행연구

2.1 SNS 개요

2.2 정보시스템 성공모형과 정보기술수용 모형

2.3 SNS 관련 연구

III. 연구모형 및 가설설정

3.1 연구모형

3.2 연구가설

\section{〈목 차〉}

3.3 연구변수의 조작적 정의

3.4 자료수집 및 연구방법

$\mathrm{IV}$. 실증분석

4.1 표본 특성

4.2 신뢰성 및 타당성 분석

4.3 가설 검증 및 분석

$\mathrm{V}$. 결 론

참고문헌

$<$ Abstract $>$

\section{I. 서 론}

인터넷이 일상생활에 널리 퍼지면서, 사람들 은 인터넷을 통해 정보를 얻기도 하고, 커뮤니케 이션 및 커뮤니티 활동을 통해 타인과 교류한다. 많은 사람들이 인터넷 상의 e-메일과 인스턴트 메신저, SNS(Social Network Service)를 사용하 면서 커뮤니케이션을 하고 있으며, 최근에는 SNS가 급성장하면서 많은 사람들이 애용하고 있다.

SNS는 인터넷 상에서 친구, 동료 등 지인과 의 인간관계를 강화하거나 새로운 인맥을 형성
함으로써 폭넓은 인적 네트워크를 구성할 수 있 게 해주는 정보서비스로, 블로그, 마이크로블로 그, 미니홈피, 커뮤니티(카페, 클럽)등을 포함한 다(한국인터넷진흥원, 2010).

국내 대표적인 SNS인 싸이월드는 2011년 3월 회원수 2,564만 명을 넘어섰고(SK커뮤니케이션 즈, 2011), 해외 서비스인 페이스북(Facebook)은 2011년 7월 기준으로 실제 사용자 수(한 달에 1 회 이상 접속하는 사용자 수)가 7억 5천만 명에 이르며(Facebook, 2001), 트위터(Twitter)는 약 2억 명의 회원수를 보유하고 있다(Twitter, 2011). SNS는 기본적으로 사용자들 간의 관계에 기

* 제주테크노파크 선임연구원, banktown@jejutp.or.kr

** 제주대학교 경영정보학과 교수, 교신저자, khkim@jejunu.ac.kr

*** 제주국제대학교 경영·세무학과 교수, jejuoh99@hanmail.net 
「정보시스템연구」제21권 제3호, 2012년 9월

반한 상호작용과 커뮤니케이션을 가능하게 하 지만, 그 서비스유형을 크게 구분하여 보면 웹기 반 SNS와 모바일 SNS로 나눌 수 있다(김해봉, 2011; 김근형, 2012). 웹기반 SNS 이용자들은 주로 미니홈피, 동호회/카페 등을 많이 사용하 고, 모바일 SNS 사용자들은 단문위주의 트위터 나 미투데이와 같은 마이크로블로그를 더 많이 이용하는 것으로 분석되었다(김해봉, 2011; 김 근형, 2012).

최근에는 스마트폰 등을 이용한 모바일 SNS 의 성장세가 눈부시며, 모바일 특유의 다양한 서 비스들이 개발되고 있는 상황이다. 2012년에는 전 세계 모바일 SNS 이용자가 8억명에 이를 것 으로 예상되고 있다(한국인터넷진흥원, 2010). 모바일 SNS는 이동성과 즉시성이 강조되는 모 바일과 접목되면서 윕기반 SNS와 차별적인 측 면이 존재하지만, 전환비용 등을 고려할 때 여전 히 웹기반 SNS에 대한 수요도 상존할 것으로 전망된다(김형민, 2010). 윕기반 SNS와 모바일 $\mathrm{SNS}$ 가 상존하는 현 상황에서 SNS사용자들이 $\mathrm{SNS}$ 의 서비스유형에 대하여 어떠한 인식차이 를 갖고 있는지 파악하는 것은 그 어느 때 보다 필요한 상황이다.

SNS는 일종의 웹사이트를 통하여 정보서비 스를 해주는 것이므로 정보시스템의 한 유형이 라고도 할 수 있다. SNS를 위하여 도입된 기술 들은 전통적인 것들이지만 새로운 응용서비스 에 적용한 것으로서, 사용자입장에서 볼 때 이전 에는 이용해보지 않았던 새로운 서비스 기능을 이용할 수 있다는 측면에서 최신정보기술로 인 식할 수 있다. 따라서, 전통적인 정보시스템 (Information System, IS)성공모형과 기술수용 모형(Technology Adaptation Model, TAM)은
SNS의 행태적 연구를 위한 기반이 될 수 있다. SNS와 관련한 많은 연구들은 사용자특성이 나 시스템특성과 같은 결정요인들이 지속사용 이나 충성도, 만족도 등에 어떠한 영향을 미치는 지 고찰하는 것들이었으며, 윕기반 SNS와 모바 일 SNS를 구분하지 않은 연구들이 대부분이었 다(서우종, 2010; 정대율, 2011; 가명호, 2011; 내가영, 2011; 신호경, 2011; Ohbyung, 2011; Olusegun, 2010;박지홍, 2008; 김상현, 2011). 김근형(2012)의 연구는 웹기반 SNS와 모바일 $\mathrm{SNS}$ 를 구분하여 분석하고 있지만, 그 연구모형 이 단순하여 각 결정요인들의 경로계수 비교를 통한 구체적인 영향력 정도를 파악하기에는 한 계가 있다.

본 논문에서는 IS성공모형과 TAM모형을 기 반으로 사용자측면과 시스템측면의 특징요인들 이 SNS의 사용자 만족도에 어떻게 영향을 미치 는지에 대한 구조모형을 도출할 것이며 이러한 구조모형의 각 경로계수들이 SNS의 서비스유 형에 따라서 어떻게 달라지는지 밝혀보고자 한 다.

\section{II. 이론적 배경 및 선행연구}

\subsection{SNS 개요}

SNS(Social Network Services)란 사회연결망 으로써, 가상공간인 인터넷 공간에서 사람들의 활동이 활발해지면서 사람들의 참여를 기반으 로 한 블로그, 싸이원드, 유튜브 등 각종 온라인 상의 매체 서비스를 말한다(허성국, 2008). 이러 한 SNS는 인터넷에서 공동의 관심사들을 가지 
<표 1> SNS 서비스유형

\begin{tabular}{|c|c|c|}
\hline 서비스유형 & 특성 & 사례 \\
\hline 웹기반 SNS & $\begin{array}{l}\text { 인터넷에서 공동의 관심사들을 가지고 있는 사용자들을 프로필, 친 } \\
\text { 구목록, 코멘트 등의 요소를 이용하여 친구에서 친구로 이동하며 프 } \\
\text { 로필을 가지고 있는 사용자와의 커뮤니케이션이 가능하도록 관계형 } \\
\text { 성을 지원하며, 인터넷과 데스크탑PC를 기본적인 접근채널로 한다. }\end{array}$ & $\begin{array}{l}\text { 카페, 클럽, 동 } \\
\text { 호회, 블로그, } \\
\text { 미니홈피 }\end{array}$ \\
\hline 모바일 SNS & $\begin{array}{l}\text { 웹기반 SNS와 비슷한 서비스 구성요소를 가지지만, 스마트폰과 같 } \\
\text { 은 모바일기기를 접근채널로 하는 것이다. 이동성과 즉시성이 강조 } \\
\text { 되는 모바일과 접목되면서 웹기반 SNS와 차별적인 측면이 존재한 } \\
\text { 다. }\end{array}$ & $\begin{array}{l}\text { 트위터, } \\
\text { 미투데이 }\end{array}$ \\
\hline
\end{tabular}

고 있는 사용자들을 프로필, 친구목록, 코멘트 등의 요소를 이용하여 친구에서 친구로 이동하 며 프로필을 가지고 있는 사용자와의 커뮤니케 이션이 가능하도록 관계형성을 지원한다. 이렇 게 형성된 지인관계를 바탕으로 친구맺기를 통 해 인맥쌓기, 구축 및 관리 등 사람과 사람들을 연결하여 그들 간의 관계맺기를 지원하는 서비 스라고 할 수 있다.

$\mathrm{SNS}$ 는 기본적으로 사용자들 간의 관계에 기 반한 상호작용과 커뮤니케이션을 가능하게 하 지만, 서비스유형을 크게 구분하여 보면 웹기반 $\mathrm{SNS}$ 와 모바일 SNS로 나눌 수 있다(김해봉, 2011).

<표 1>은 SNS 서비스유형을 나타내고 있다.

\section{2 정보시스템 성공모형과 정보기술 수용모형}

DeLone \& McLean(1992)의 정보시스템 성 공 모형은 시스템 품질, 정보 품질이 시스템 사 용, 사용자 만족에 영향을 주고 시스템 사용과 사용자 만족은 개인의 성과 및 조직의 성과에 영향을 미침을 나타내고 있다. 그러나, DeLone
\& McLean은 정보시스템의 역할 변화와 기존 모형과 관련된 이슈들을 보완하여 수정된 정보 시스템 성공모형을 제안하였다(DeLone \& McLean, 2003). 수정된 모형에서는 정보품질과 시스템품질을 외생변수로 하고, 지각된 유용성 을 매개변수, 사용자만족도를 종속변수로 설정 하여 분석하고 있다. 사용자 컴퓨팅 환경의 변화 에 따라 정보시스템 담당 조직이 정보와 서비스 를 동시에 제공함을 감안하여 IS(Information Systems) 조직의 서비스의 질을 IS 성공모형 (2003) 차원에 포함하였으며 정보시스템 영향 의 영역인 개인에 대한 영향과 조직에 대한 영향 을 순효과(net bebefit)라는 하나의 차원으로 통 합하였다.

Seddon(1997)은 DeLone \& McLean의 모형 을 수정하여 새로운 모형을 세웠다. Seddon은 DeLone \& McLean(1992) 모형에서 사용도 변 수는 지각된 용이성으로 대체되는 것이 더 바람 직하다고 하였다. 왜냐하면, 정보시스템을 많이 사용하는 것보다는 사용함으로써 얻는 이익이 있어야만 성공적인 정보시스템이라고 할 수 있 기 때문에 시스템 사용이라는 항목은 사용으로 부터 얻는 효익을 가리킨다고 하였다. 
「정보시스템연구」 제21권 제3호, 2012년 9월

Davis(1989)의 기술수용모형 (Technology Acceptance Model; TAM)은 합리적행위이론 (TRA: theory of reaasoned action)을 이론적 기 반으로 새로운 기술을 수용하기 위한 과정을 이 용용이성과 유용성이라는 두 개념을 통해 설명 하는 이론이다(Davis, 1989). TAM에서는 매개 변수로 지각된 용이성(Perceived Ease of Use) 과 지각된 유용성(Perceived Usefulness)을 제시 하였고 이를 이용하여 새로운 기술을 수용하려 는 태도와 실제 사용 간의 관계를 표현하였다. Davis(1986)의 TAM 모형은 지나치게 단순하 며 기술에 대한 사용자의 판단만을 강조한다는 단점이 지적되었으며, 이에 따라 Venkatesh 와 Davis(2000)는 확장된 기술수형모형(Extend Technology Acceptance Model: ETAM)을 제 시하였다. ETAM의 외부변수로는 많은 연구들 에서 제시되었으며, 대체로 사용자의 혁신적 성 격, 사회적 영향 및 압력, 컴퓨터 경험, 최고 경 영층의 지원, 성별, 사용자 참여나 몰입, 정보시 스템의 질 등이 많이 사용되고 있다.

Davis(1989)가 TAM모델을 발표한 이후, 정 보기술수용 분야에서 많은 다양한 논문들이 지 각된 유용성과 지각된 용이성에 대한 타당성, 유 용성을 검증하였지만, 김상현(2010)은 TAM모 형을 활용한 많은 연구들 중에서 지각된 유용성 이 용이성보다 더 중요한 요소로 나타났다고 설 명하고 있다. 또한, 많은 연구자들이 유용성에 미치는 외부변수와 지각된 용이성에 영향을 미 치는 외부변수에 대하여 연구하였다. 외부변수 들은 정보기술의 특성과 상황에 맞게 구체화시 켜 삽입하거나 혹은 태도외의 매개변수를 추가 하거나 제외시켜 확장하고 있는데, 이때 주로 거 론되었던 외부요인은 수용자 특성, 특정기술의
특성변인, 사회문화적 영향 등이다(강재은, 2011).

\subsection{SNS 관련 연구}

Smith(2007)은 SNS 서비스의 특징을 다음과 같이 크게 7 가지로 구분하여 제시하였다. 즉, 자 기를 드러내기 위한 표현(presentation) 속성, 각 종 정보와 콘텐츠를 나누기 위한 공유(sharing) 속성, 커뮤니케이션을 위한 대화(conversation) 속성, 단체 활동을 위한 그룹(group) 속성, 자신 의 홍보와 명성을 알리기 위한 평판(reptuation) 속성, 인맥을 구축하고 유지하기 위한 관계 (relationships) 속성, 자신의 주체성을 표현하기 위한 정체성(identity) 속성이다. 현재 서비스를 제공하고 있는 SNS 제공업체들은 자신의 서비 스 형태와 경쟁 전략에 따라 차별적인 특징들을 강조할 수 있다.

박지홍(2008)은 SNS 사용자의 지속적 사용 의도에 영향을 미치는 요인들에 관하여 탐구하 였다. 평판도, 관계적 가치, 지식품질, 적합성, 개인화, 만족도가 지속적 사용의도에 영향을 미 치는 것으로 나타나고 있다. 서우종(2010)은 SNS의 품질과 사용자 만족, 지속적 사용의도, 구전의도와의 관계를 실증적으로 입증하였다. 독립변수로는 인터페이스 품질, 시스템 품질, 정 보 품질, 서비스 품질, 감성 품질, 저작환경 품질 등의 6개의 SNS 웹사이트 품질 영역들을 놓고, 매개변수로는 사용자 만족, 지속적 사용의도, 종 속변수로는 구전의도를 설정하여 분석한 결과, 감성 품질, 저작환경 품질, 시스템 품질 영역이 $\mathrm{SNS}$ 에 대한 사용자 만족에 영향을 미치는 것으 로 나타났다. 또한 SNS에 대한 사용자 만족은 
지속적 사용의도와 구전의도에 영향을 미치는 것으로 나타났다. Ohbyung(2010)은 SNS의 수 용에 영향을 미치는 개인의 특성들을 사회적 실 재감(social identity), 이타심(altruism), 원격현 장감(telepresence) 등으로 설정하고, 인지된 고 무(perceived encouragement)를 매개변수로, SNS 사용을 종속변수로 하여 실증분석을 수행 한 결과, 인지된 고무가 SNS의 수용을 결정하는 주요요인임을 밝혀내었다. Olusegun (2010)은 SNS의 사용을 혁신의 확산(DOI, Diffusion of Innovations)으로 간주하여 양립성(compability) 과 시험가능성(trialability)이 SNS의 사용을 위 한 태도에 영향을 미치는 요인이라고 주장하고 있다. 내가영(2010)은 모바일 SNS의 이용동기 요인들을 도출하고 이러한 것들 중에서 만족감 에 영향을 미치는 요인들은 타인과의 커뮤니케 이션, 관계형성의 유용성, 정보성, 이용의 용이 함 등이라고 주장하고 있다. 정대율(2011)은 SNS의 이용욕구충족과 재방문에 영향을 미치 는 요인에 대하여 분석하였다. 유희성, 콘덴츠 매력도, 대인효용성을 독립변수로, 유용성과 태 도, 의사소통만족도, 옥구충족은 매개변수, 재방 문을 종속변수로 하여 연구를 실시하였다. 가명 호(2011)은 SNS의 e-고객충성도에 관하여 실증 연구를 하였다. 세 개의 독립요인(시스템 능력, 정보 적절성, 콘텐츠 가치)과 두 개의 매개요인 (사이트 매력도, e-고객만족), 고객충성도를 종 속요인으로 하여 고객충성도의 영향요인들을 분석하였다. 실증연구 결과 정보 적절성과 콘텐 츠 가치가 사이트 매력도에 직접 영향을 미치며, 이는 다시 고객만족을 통하여 고객의 충성도에 간접적으로 영향을 미치는 것으로 나타났다. 김 상현(2011)은 소셜커머스 특징과 개인특징이
신뢰와 신뢰성과에 미치는 영향에 관하여 연구 하였다. 소셜커머스의 특성(명성, 경제성, 정보 품질, 거래안정성, 상호작용성)과 개인특성(신 뢰성향, 구매경험, 구전효과)을 독립요인으로, 신뢰를 매개요인으로, 구매의도를 종속요인으 로 설정하여 연구를 수행하였다.

소셜커머스 특성과 개인특성의 구매경험과 구전효과는 신뢰형성에 영향을 미치는 것으로 나타났으며 신뢰는 구매의도에 영향력을 가지 는 것으로 나타났다. 신호경(2011)은 셜네트워 크서비스에서의 정보공유에 미치는 영향요인에 관하여 연구하였다. 독립변수로는 감정적 애착 과 자기표현, 매개변수로는 만족도, 종속변수로 는 정보공유를 설정하여 분석하였다. SNS사용 자의 감정적 애착이 사용자 만족 및 정보공유에 긍정적 영향을 미치며 사용자 만족은 정보공유 에 대해 긍정적인 영향을 미치는 것으로 나타났 다. 차상민(2011)은 사회적 실재감, 개인의 정체 성, 커뮤니케이션, 관계 등이 SNS의 특징이라고 간주하면서 독립변수로 설정하고, 소속감을 매 개변수로, 몰입을 독립변수로 설정하면서 연구 하였다.

사회적 실재감과 커뮤니케이션, 관계 등은 소 속감에 영향을 미치고 소속감은 인지적 몰입에 영향을 미친다고 주장하였다. 김근형(2012)은 SNS의 사용자만족도에 미치는 영향요인으로 개인혁신성, 사회적영향, 정보품질, 시스템품질 을 설정하여 분석하였다.

<표 2>는 SNS 관련 연구들의 연구모형을 분석하여 독립변수와 매개변수, 종속변수에 속 하는 요인들을 분리하여 나타내고 있다. 
「정보시스템연구」제21권 제3호, 2012년 9월

<표 2> SNS 관련 연구들의 연구모형 분석

\begin{tabular}{|c|c|c|c|c|}
\hline \multirow{2}{*}{ 연구내용 } & \multicolumn{2}{|c|}{ 독립변수 } & \multirow{2}{*}{ 매개변수 } & \multirow{2}{*}{ 종속변수 } \\
\hline & 사용자측면 & 시스템측면 & & \\
\hline 박지홍(2008) & $\begin{array}{l}\text { 평판도, 관계적가치, 개인화, 적 } \\
\text { 합성 }\end{array}$ & 지식품질 & 만족도 & 지속의도 \\
\hline 서우종(2010) & & $\begin{array}{l}\text { 인터페이스 품질, 시스템 품질, } \\
\text { 정보 품질, 서비스 품질, 감성 품 } \\
\text { 질, 저작환경 품질 }\end{array}$ & $\begin{array}{l}\text { 만족도, 지속사 } \\
\text { 용의도 }\end{array}$ & 구전의도 \\
\hline 내가영(2010) & $\begin{array}{l}\text { 커뮤니케이션, } \\
\text { 관계형성, 정보성 } \\
\text { 용이성 }\end{array}$ & & & 사용만족 \\
\hline $\begin{array}{l}\text { Olusegun } \\
\text { (2010) }\end{array}$ & $\begin{array}{l}\text { 상대적 이점(relative advantage), } \\
\text { 관찰성(observability), 시험가 } \\
\text { 능성(trialability) }\end{array}$ & 복잡성(complexibility) & 태도 & $\begin{array}{l}\text { 시스템 } \\
\text { 사용 }\end{array}$ \\
\hline 정대율(2011) & 유희성, 대인효용성 & 콘텐츠 매력도 & $\begin{array}{l}\text { 유용성, 태도, 의 } \\
\text { 사소통만족도, } \\
\text { 욕구충족 }\end{array}$ & 재방문 \\
\hline 가명호(2011) & & $\begin{array}{l}\text { 시스템 능력, 정보 적절성, 콘텐 } \\
\text { 츠 가치 }\end{array}$ & $\begin{array}{l}\text { 사이트 매력도, } \\
\text { e-고객만족 }\end{array}$ & $\begin{array}{l}\text { 고객 } \\
\text { 충성도 }\end{array}$ \\
\hline 김상현(2011) & 신뢰성향, 구매경험, 구전효과 & $\begin{array}{l}\text { 정보품질, 거래안정성, 상호작 } \\
\text { 용성, 명성, 경제성 }\end{array}$ & 신뢰 & 구매의도 \\
\hline 신호경(2011) & 감정적 애착, 자기표현 & & $\begin{array}{l}\text { 사용자 } \\
\text { 만족 }\end{array}$ & 정보공유 \\
\hline 차상민(2011) & $\begin{array}{l}\text { 사회적 실재감, 개인의 정체성, } \\
\text { 커뮤니케이션, 관계 }\end{array}$ & & 소속감 & $\begin{array}{l}\text { 인지적 } \\
\text { 몰입 }\end{array}$ \\
\hline $\begin{array}{l}\text { Ohbyung } \\
\text { (2011) }\end{array}$ & $\begin{array}{l}\text { 사회적 실재감(social identity), } \\
\text { 이타심(altruism), 원격현장감 } \\
\text { (telepresence), }\end{array}$ & & $\begin{array}{l}\text { 인지된 고무 } \\
\text { (perceived } \\
\text { encouragement) }\end{array}$ & $\begin{array}{l}\text { 시스템 } \\
\text { 사용 }\end{array}$ \\
\hline 김근형(2012) & 개인혁신성, 사회적영향 & 정보품질, 시스템품질 & & $\begin{array}{l}\text { 사용자 } \\
\text { 만족도 }\end{array}$ \\
\hline
\end{tabular}

\section{III. 연구모형 및 가설설정}

\section{1 연구모형}

본 연구의 연구모형은 SNS가 최신정보기술
의 한 유형이라는 관점에서 Seddon의 정보시스 템 성공모형과 ETAM 모형을 기본 토대로 하였 다. 또한, 기존 SNS 관련 연구모형들이 사용자 특성과 시스템특성에 속하는 외생변수들을 사 용한 것을 수용하여, 본 연구모형의 외생변수들 도 SNS의 사용자 측면과 시스템 측면의 특성이 


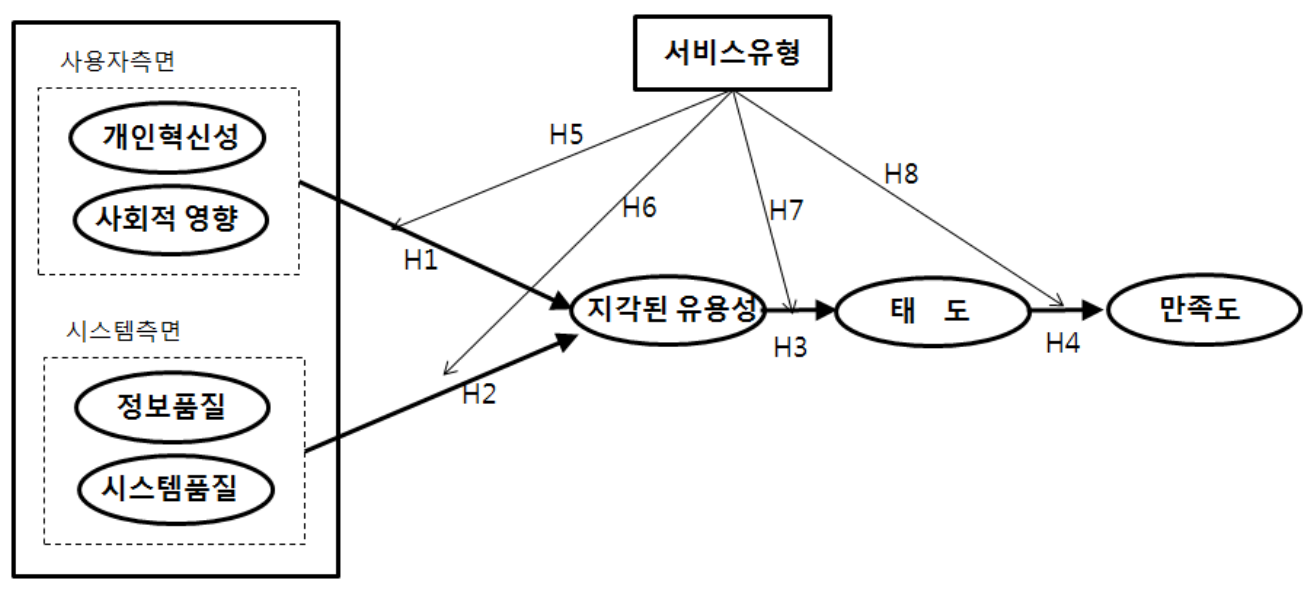

<그림 1> 연구모형

반영될 수 있도록 하였다.

연구모형에서의 연구변수들은 개인혁신성, 사회적 영향, 정보품질, 시스템품질, 지각된 유 용성, 태도, 사용자 만족도, 서비스유형 등으로 구성된다.

<그림 1>은 본 연구의 연구모형을 나타내고 있다. 독립변수로는 SNS의 사용자특성과 시스 템특성을 나타내도록 하였다. SNS의 사용자특 성은 다양하게 연구되었지만, ETAM에서 주요 한 외부변수로 연구되었던 개인혁신성과 사회 적 영향을 선택하였다. 특히, 사회적 영향은 SNS의 특징도 내포하는 변수이다. SNS의 시스 템 특성은 정보시스템 성공모형의 독립변수인 정보품질과 시스템품질을 사용하였다. 매개변 수로는 TAM모형의 지각된 유용성과 태도를 사 용하였다. 지각된 용이성은 TAM모형을 활용한 많은 연구들 중에서 지각된 유용성에 비하여 덜 중요한 것으로 나타났으며, 시스템품질 요인과 중복될 수 있기 때문에 제외되었다. 종속변수로 는 사용자 만족도를 설정하였다.

본 연구에서는 SNS의 사용자특성과 시스템 특성이 지각된 유용성이나 태도 및 만족도에 어
떠한 영향을 미치는지 알아볼 것이다. 또한, 지 각된 유용성은 태도 및 만족도에 어떠한 영향을 미치는지, 태도는 만족도에 어떠한 영향을 미치 는지 알아보고자 한다. 특히, SNS의 서비스유형 (즉, 웹기반 SNS와 모바일 SNS)에 따라 각 연구 변수들의 영향정도가 어떻게 달라지는지 살펴 보고자 한다.

\section{2 연구가설}

확장된 TAM모형에서 자주 사용되는 외부변 수로는 사회적 영향 및 압력, 정보시스템의 품 질, 컴퓨터 경험, 혁신적 성격, 자기 효능 등이 있다. 이 중 가장 많이 거론되는 것이 사용자의 혁신성이다. 혁신성은 개인에 의해 새로운 것으 로 지각되는 개념, 관행, 사물을 의미하며 새로 움이란 개인에 따른 주관적인 새로움을 말하는 것으로서, 한 시스템에 대해 다른 구성원보다 상 대적으로 조기에 새로운 아이디어를 수용하는 정도라 할 수 있다(Rogers, 1995).

사회적 영향은 '새로운 정보시스템을 사용하 는데 있어서 중요하게 고려되는 사람들의 믿음 
「정보시스템연구」제21권 제3호, 2012년 9월

에 대하여 지각하는 정도'로서, 확장된 TAM모 형 뿐만 아니라 많은 SNS 관련 연구에서 독립변 수로 나타나고 있다(박지홍, 2008; 내가영, 2010; 차상민, 2011; Ohbyung,2011). 특히, 사 회적 영향은 Smith가 제시한 SNS의 7가지 특징 중에서 표현속성, 그룹속성, 평판속성, 관계속성 등과 일맥상통하는 측면이 있다. SNS특징을 선 호하는 성향의 사용자는 SNS특징을 충실하게 제공하는 SNS에 대해서는 유용성을 느낄 것이 지만, 그렇지 못한 SNS에 대해서는 부정적인 반 응을 나타낼 것이다.

정보품질과 시스템품질은 정보시스템 사용 자 만족도에 영항을 미치는 독립변수로 나타나 고 있다. DeLone \& McLean(1992)는 정보품질 에 대해서 시스템이 생산해 내는 정보의 품질을 의미하는 것으로 규정하였으며 정보시스템의 성공에 매우 중요한 역할을 한다고 주장하고 있 다. McKinny, Yoon \& Zahedi(2002)는 웹고객 만족을 측정하는 연구에서 정보품질을 타당성, 이해가능성, 신뢰성, 적절성, 범위, 사용 가능성 으로 구성하였고, 모두 만족도에 유의한 영향을 미침을 검증하였다. De Wulf(2006)은 정보시스 템이 제공하는 정보는 믿을 수 있는 최신 정보이 어야 하고, 이해하기 쉬울수록 사용자의 태도에 긍정적인 영향을 미친다고 주장하였다. DeLone \& McLean(1992)은 시스템 품질에 대하여 정보 를 전달하는 시스템의 성능이라고 정의하였으 며 사용자의 만족도에 영향을 미치는 핵심 요인 중 하나라고 주장하였다. 정보시스템이 아무리 높은 품질의 정보와 서비스를 제공한다고 할지 라도 페이지 전환속도가 느리거나 접속이 자주 끊기는 등 원활하게 정보를 전달하지 못한다면 정보시스템에 대하여 불안정한 인식을 갖게 될
것이고, 경우에 따라서는 사용하던 정보시스템 사용을 중단하는 상황이 나타날 수 있다 (McKinney \& Yoon, 2002). 김경남(2011)은 스 마트폰의 기능적 측면에서 정보의 신속성과 사 용편리성이 업무성과에 영향을 미친다고 주장 하였다.

SNS와 관련한 많은 연구들에서도 정보품질 과 시스템품질은 주요 독립변수로 나타나고 있 다(박지홍, 2008; 서우종, 2010; 가명호, 2011; 김상현, 2011)

본 연구에서는 이러한 연구결과들을 바탕으 로 다음과 같이 가설을 설정하였다.

<연구가설 H1> SNS의 사용자특성은 지각된 유용 성에 유의한 영향을 미칠 것이다.

<세부가설 H1a> SNS 사용자의 개인혁신성은 지각된 유용성에 유의한 영향을 미칠 것이다.

<세부가설 H1b> SNS 사용자의 사회적 영향은 지각된 유용성에 유의한 영향을 미칠 것이다.

<연구가설 H2> SNS의 시스템특성은 지각된 유용 성에 유의한 영향을 미칠 것이다.

<세부가설 $\mathrm{H} 2 \mathrm{a}>\mathrm{SNS}$ 의 정보품질은 지각된 유 용성에 유의한 영향을 미칠 것이다.

<세부가설 H2b> SNS의 시스템품질은 지각된 유용성에 유의한 영향을 미칠 것이다.

Davis(1989)는 지각된 유용성에 대하여 미래 혜택에 대한 기대라고 정의하고 있으며, Seddon(1997)은 과거사용으로 인한 혜택에 대 한 태도라고 정의하고 있다. Ajzen(1988)은 태 도에 대하여 "대상, 사람, 제도, 사건 또는 개인 의 세상에서 호의적 또는 비호의적으로 반응하 
는 경향”이라고 정의하고 있다. TAM과 확장된 $\mathrm{TAM}$ 에 따르면, 지각된 유용성은 자발적이거나 의무적 맥락 모두에서 신기술 사용의도를 향상 시킨다고 하였다(Venkatesh et al., 2003). 이러 한 결과는 SNS와 같은 새로운 정보기술 수용에 서도 나타나고 있다. 정대율(2011)은 SNS연구 에서 지각된 유용성이 태도에 유의한 영향을 미 친다고 하였다.

본 연구에서는 이러한 연구결과들을 바탕으 로 다음과 같이 가설을 설정하였다.

<연구가설 $\mathrm{H} 3>\mathrm{SNS}$ 에 대한 지각된 유용성은 태 도에 유의한 영향을 미칠 것이다.

정보시스템 연구에서 사용자 만족은 실제 시 스템의 성능이나 효과성과 같은 정보시스템 성 공의 대체변수로 사용되어 왔다(DeLone \& McLean, 1992; Gatian, 1994). 객관적인 측정이 용이하지 않은 정보시스템 성능이나 효과는 시 스템 사용 후 사용자가 종합적으로 인지하는 만 족에 의하여 적절하게 설명될 수 있다고 보았기 때문이다. 확장된 TAM모형에서는 기술 수용자 의 태도가 수용의도에 영향을 미친다고 보았으 며, Olusegun (2010)은 SNS 관련 연구에서 사 용자의 태도가 시스템 사용에 영향을 미친다고 주장하였다.

본 연구에서는 이러한 연구결과들을 바탕으 로 다음과 같이 가설을 설정하였다.

<연구가설 $\mathrm{H} 4>\mathrm{SNS}$ 에 대한 태도는 만족도에 유 의한 영향을 미칠 것이다.

SNS의 서비스유형을 크게 구분하여 보면 웹 기반 SNS와 모바일 SNS로 나눌 수 있다(김해
봉, 2011; 김근형, 2012). 웹기반 SNS는 미니홈 피 및 블로그, 동호회 및 카페 등에 해당되며 모바일 SNS는 단문 위주의 트위터나 미투데이 와 같은 마이크로블로그 등에 해당된다. 모바일 SNS는 웹기반 SNS와 동일한 서비스 구성요소 를 가지고 모바일 기기를 통해서 이용하는 것이 다. 따라서, 모바일 SNS와 웹기반 SNS는 서로 비슷한 측면이 있다. 그러나, 모바일 SNS는 이 동성과 즉시성이 강조되는 모바일 특징을 가지 면서 웹기반 SNS와 차별화되는 부분이 존재한 다. 기본적으로는 SNS를 즐긴다는 점에서는 변 함이 없지만, 모바일 SNS 사용자들은 웹기반 $\mathrm{SNS}$ 에 비하여 매우 적극적인 활동을 하는 것으 로 조사되었다(제일기획, 2010). 이들은 일상 기 록이나 지인과의 교류보다는 최신 유행이나 트 랜드 파악과 같은 새로움을 따라가려는 욕구가 강했고, 지인보다는 각 분야 전문가에 대한 관심 이 높았다. 또한 관련조사를 통해 모바일 SNS 사용자들의 특징은 사회 참여적이며 인맥이 넓 고, 사회적 지위에 민감할 뿐만 아니라 새로운 것에 개방적인 개방적인 태도를 갖고 있었다(유 진, 2011).

이러한 연구결과들을 바탕으로, 본 논문에서 는 SNS의 서비스유형을 웹기반 SNS와 모바일 SNS로 구분하여 다음과 같은 가설을 설정하였 다.

<연구가설 H5> SNS의 사용자특성이 지각된 유용 성에 미치는 영향은 SNS 서비스유형에 따 라 차이를 보일 것이다.

<세부가설 H5a> SNS 사용자의 개인혁신성이 지각된 유용성에 미치는 영향은 SNS 서비스유형에 따라 차이를 보일 것이 다. 
「정보시스템연구」제21권 제3호, 2012년 9월

<세부가설 H5b> SNS 사용자의 사회적 영향이 지각된 유용성에 미치는 영향은 SNS 서비스유형에 따라 차이를 보일 것이 다.

<연구가설 H6> SNS의 시스템특성이 지각된 유용 성에 미치는 영향은 SNS서비스유형에 따
라 차이를 보일 것이다. <세부가설 H6a> SNS의 정보품질이 지각된 유 용성에 미치는 영향은 SNS 서비스유형 에 따라 차이를 보일 것이다.

<세부가설 H6b> SNS의 시스템품질이 지각된 유용성에 미치는 영향은 SNS 서비스유 형에 따라 차이를 보일 것이다.

<표 3> 연구변수의 개념적 정의와 조작적 정의

\begin{tabular}{|c|c|c|c|c|}
\hline \multicolumn{2}{|c|}{ 연구변수 } & 개념적 정의 & $\begin{array}{l}\text { 측정 } \\
\text { 변수 }\end{array}$ & 조작적 정의 \\
\hline \multirow{6}{*}{$\begin{array}{l}\text { 사 } \\
\text { 용 } \\
\text { 자 } \\
\text { 측 } \\
\text { 면 }\end{array}$} & \multirow{3}{*}{$\begin{array}{l}\text { 개 } \\
\text { 인 } \\
\text { 혁 } \\
\text { 신 } \\
\text { 성 }\end{array}$} & \multirow{3}{*}{$\begin{array}{l}\text { 특정 개인이 사회시스템내 } \\
\text { 에 있는 다른 수용자들에 앞 } \\
\text { 서 혁신을 채택하는 정도 }\end{array}$} & $\mathrm{x} 1$ & 새로운 기능에 즉각적 반응 \\
\hline & & & $\mathrm{x} 2$ & 최신 정보기술에 대한 호기심 \\
\hline & & & x3 & 최신제품 사용에 대한 충동 \\
\hline & \multirow{3}{*}{$\begin{array}{l}\text { 사 } \\
\text { 회 } \\
\text { 적 } \\
\text { 영 } \\
\text { 향 }\end{array}$} & \multirow{3}{*}{$\begin{array}{l}\text { 개인의 사회적 관계속에서 } \\
\text { 중요하게 고려되는 사람들 } \\
\text { 로부터 영향을 받는 정도 }\end{array}$} & $\mathrm{x} 4$ & 타인으로부터 호평을 받기 위한 수단 \\
\hline & & & $\mathrm{x} 5$ & 개성표출의 수단 \\
\hline & & & $\mathrm{x} 6$ & 타인과의 관계형성 수단 \\
\hline \multirow{6}{*}{$\begin{array}{l}\text { 시 } \\
\text { 스 } \\
\text { 템 } \\
\text { 측 } \\
\text { 면 }\end{array}$} & \multirow{3}{*}{$\begin{array}{l}\text { 정 } \\
\text { 보 } \\
\text { 품 } \\
\text { 질 }\end{array}$} & \multirow{3}{*}{$\begin{array}{l}\text { 시스템이 생산해내는 정보 } \\
\text { 의 질적 수준 }\end{array}$} & $\mathrm{x} 7$ & 용이한 정보를 제공하는 정도 \\
\hline & & & x8 & 다양한 정보를 제공하는 정도 \\
\hline & & & x9 & 최신 정보를 제공하는 정도 \\
\hline & \multirow{3}{*}{$\begin{array}{l}\text { 시 } \\
\text { 스 } \\
\text { 템 } \\
\text { 품 } \\
\text { 질 }\end{array}$} & \multirow{3}{*}{ 시스템의 질적 수준 } & $\mathrm{x} 10$ & 화면 전환속도의 신속성 \\
\hline & & & x11 & 쉽게 이용할 수 있는 정도 \\
\hline & & & $\mathrm{x} 12$ & 오류없이 정상적으로 작동하는 정도 \\
\hline \multirow{3}{*}{\multicolumn{2}{|c|}{$\begin{array}{l}\text { 지각된 } \\
\text { 유용성 }\end{array}$}} & \multirow{3}{*}{$\begin{array}{l}\mathrm{SNS} \text { 를 이용하는 것이 개인 } \\
\text { 의 업무성과를 향상시킬 것 } \\
\text { 이라고 사용자가 믿는 정도 }\end{array}$} & $\mathrm{y} 1$ & 획득한 정보가 사용자에게 유용한 정도 \\
\hline & & & y2 & $\begin{array}{l}\text { 획득한 정보가 사용자의 업무처리 시간을 절약해 } \\
\text { 주는 정도 }\end{array}$ \\
\hline & & & y3 & $\begin{array}{l}\text { 획득한 정보가 사용자의 업무처리 효율성을 증가 } \\
\text { 시키는 정도 }\end{array}$ \\
\hline \multirow{3}{*}{\multicolumn{2}{|c|}{ 태도 }} & \multirow{3}{*}{$\begin{array}{l}\text { 시스템에 대한 호의적 또는 } \\
\text { 비호의적 반응 정도 }\end{array}$} & y4 & 재미있는 정도 \\
\hline & & & y5 & 흥미로움 \\
\hline & & & y6 & 매력적임 \\
\hline \multirow{3}{*}{\multicolumn{2}{|c|}{ 만족도 }} & \multirow{3}{*}{$\begin{array}{l}\mathrm{SNS} \text { 의 기능 및 정보에 대한 } \\
\text { 기대에 비하여 결과가 충분 } \\
\text { 한 정도 }\end{array}$} & y7 & 제공된 정보에 대한 만족 정도 \\
\hline & & & y8 & 시스템 기능에 대한 만족 정도 \\
\hline & & & y9 & 전반적인 만족 정도 \\
\hline \multicolumn{2}{|c|}{$\begin{array}{l}\text { 서비스 } \\
\text { 유형 }\end{array}$} & SNS의 서비스유형 & $\mathrm{x} 13$ & $\begin{array}{l}\text { 1. 웹기반 SNS } \\
\text { 2. 모바일 SNS }\end{array}$ \\
\hline
\end{tabular}


<연구가설 H7> SNS에 대한 지각된 유용성이 태 도에 미치는 영향은 SNS 서비스유형에 따 라 차이를 보일 것이다.

<연구가설 H8> SNS에 대한 태도가 만족도에 미 치는 영향은 SNS 서비스유형에 따라 차이 를 보일 것이다.

\section{3 연구변수의 조작적 정의}

연구모형 및 가설에서 언급되었던 연구변수 들의 개념과 조작적 정의는 이전 연구들의 결과 를 바탕으로 SNS 특성이 반영될 수 있도록 수정 하여 <표 3>과 같이 설정하였다.

\section{4 자료수집 및 연구방법}

본 연구의 목적을 달성하기 위하여 자료의 수 집과 측정을 위한 조사방법으로 구조화된 설문 지를 작성 배포하였다. 설문지는 <표 3>에 나타
난 측정변수의 조작적 정의를 바탕으로 개인혁 신성 3개 문항, 사회적 영향 3 개 문항, 정보품질 3 개 문항, 시스템품질 3 개 문항, 지각된 유용성 3 개 문항, 태도 3 개 문항, 만족도 3 개 문항으로 하여 리커드식 5점 척도로 구성하였으며, 추가 적으로 SNS의 서비스유형과 관련하여 1 개 문 항, 기타 인구통계적 특성을 묻는 문항들로 구성 하였다.

본 설문조사는 SNS를 이용했던 사용자들을 대상으로 2011년 10월 12일부터 10월31까지 3 주일간 온라인 설문방식으로 실시하였으며, 수 거된 설문지 중 불성실하게 응답한 설문지를 제 외한 278부를 실증분석에 사용하였다.

수집된 자료의 코딩은 Excel 2007 프로그램 을 이용하였고, 통계분석을 위한 패키지로는 AMOS 18.0을 이용하였다. 분석방법으로는 빈 도분석, 확인적 요인분석, 경로분석, 조절효과 분석 등을 실시하였다.

<표 4> 인구통계학적 특성

\begin{tabular}{|c|c|c|c|c|}
\hline \multicolumn{2}{|c|}{ 구분 } & 빈도수 & 비율(\%) & 합계 \\
\hline \multirow{2}{*}{ 성별 } & 남 & 183 & 65.8 & \multirow{12}{*}{278} \\
\hline & 여 & 95 & 34.2 & \\
\hline \multirow{4}{*}{ 나이 } & 10대 & 52 & 18.7 & \\
\hline & 20대 & 156 & 56.1 & \\
\hline & 30대 & 51 & 18.3 & \\
\hline & 40대 이상 & 19 & 6.8 & \\
\hline \multirow{6}{*}{ 직업 } & 중 - 고등학생 & 51 & 18.3 & \\
\hline & 대학(원)생 & 144 & 51.8 & \\
\hline & 일반사무직 & 52 & 18.7 & \\
\hline & 자영업 & 5 & 1.8 & \\
\hline & 전문직 & 25 & 9.0 & \\
\hline & 기타 & 1 & 0.4 & \\
\hline
\end{tabular}




\section{IV. 실증분석}

\section{1 표본 특성}

수집된 자료의 인구통계학적 특성을 살펴보 기 위해 성별, 연령, 직업, SNS 이용현황 등의 변수들에 대하여 빈도분석을 수행한 결과 <표 $4>$ 와 <표 5>와 같이 나타났다.

SNS는 남성이 여성보다 높은 비율로 사용하 고 있으며 비교적 젊은 층인 20대에서 많이 사
용하고 있음을 알 수 있다.

또한, 이용환경은 유선환경(데스크탑 PC)보 다 무선환경(스마트폰 방식)을 선호하고 있다.

\section{2 신뢰성 및 타당성 분석}

본 논문에서는 연구변수에 대한 측정도구의 신뢰성과 타당성을 검증하기 위하여 확인요인 분석을 수행하였다.

구성개념과 변수구성의 최적상태 여부를 확

<표 5> 인터넷 및 SNS 이용현황에 대한 빈도분석

\begin{tabular}{|c|c|c|c|}
\hline \multicolumn{2}{|r|}{ 구분 } & 빈도수 & 비율(\%) \\
\hline \multirow{5}{*}{ 인터넷 이용시간 } & 2시간 미만 & 91 & 32.7 \\
\hline & $2 \sim 4$ 시간 & 102 & 36.7 \\
\hline & $4 \sim 6$ 시간 & 37 & 13.3 \\
\hline & $6 \sim 8$ 시간 & 21 & 7.6 \\
\hline & 8시간 이상 & 27 & 9.7 \\
\hline \multirow{5}{*}{$\begin{array}{c}\text { SNS } \\
\text { 이용시간 }\end{array}$} & 2시간 미만 & 179 & 64.4 \\
\hline & $2 \sim 4$ 시간 & 57 & 20.5 \\
\hline & $4 \sim 6$ 시간 & 22 & 7.9 \\
\hline & $6 \sim 8$ 시간 & 7 & 2.5 \\
\hline & 8시간 이상 & 13 & 4.7 \\
\hline \multirow{4}{*}{ SNS 이용동기 } & 자발적 & 239 & 86.0 \\
\hline & 강제적 & 3 & 1.1 \\
\hline & 주변 권유 & 34 & 12.2 \\
\hline & 기타 & 2 & 0.7 \\
\hline \multirow{7}{*}{ SNS 이용목적 } & 인맥관리 & 49 & 17.6 \\
\hline & 자기표현 공간 & 37 & 13.3 \\
\hline & 의사소통 & 94 & 33.8 \\
\hline & 여가 및 취미 & 58 & 20.9 \\
\hline & 정보·지식 획득 및 공유 & 37 & 13.3 \\
\hline & 경제활동 & 1 & 0.4 \\
\hline & 기타 & 2 & 0.7 \\
\hline \multirow{2}{*}{$\begin{array}{c}\text { 주로 사용하는 } \\
\text { SNS }\end{array}$} & 웹기반 & 201 & 72.3 \\
\hline & 모바일SNS & 77 & 27.7 \\
\hline \multicolumn{2}{|c|}{ 합 계 } & 278 & 100 \\
\hline
\end{tabular}


인하기 위하여 모형적합도를 평가하였는데, 몇 몇 적합도 지수가 권장기준에 미달(GFI=.882, $\mathrm{NFI}=890$ )하는 것으로 나타났다. 따라서, 모형 적합도를 향상시키기 위하여 수정지수 (Modification Index)를 사용하였으며 수정지수 값이 큰 순서로 측정변수 $\mathrm{x} 7, \mathrm{y3}, \mathrm{y} 6$ 을 제거하였 다. 수정모형의 적합도지수는 <표 6>에서 처럼, CFI, NFI 등 주요지수가 양호한 값 $\left(\mathrm{X}^{2}=\right.$ 130.1900( $\mathrm{p}=.016), \mathrm{RMSEA}=0.034, \mathrm{CFI}=.986$, $\mathrm{AGFI}=.920$ )으로 나타나 수용하는데 무리가 없 는 것으로 판단하였다.
확인요인분석에서 측정변수의 신뢰성 검사 를 위해서는 3 가지를 권장한다(김대업, 2008). 첫째, 개념변수가 측정변수에 주는 영향인 $\lambda^{2}$ (표준적재치의 제곱)이 0.5 이상, 둘째, 개념신 뢰성(construct reliability)이 0.7 이상, 셋째, AVE (Average Variance Extracted)가 0.5이상 되어야 한다. <표 6>은 확인요인분석 결과를 나 타내고 있다. 모든 측정변수의 $\lambda^{2}$ 이 0.5 이상이 거나 0.5 에 근접하고 있으며, 각 개념변수의 개 넘신뢰도가 0.7 이상, AVE 값이 0.5이상을 나타 내는 것으로 보아 측정변수의 신뢰성은 확보된

<표 6> 확인요인분석 결과

\begin{tabular}{|c|c|c|c|c|c|c|}
\hline $\begin{array}{l}\text { 개념 } \\
\text { 변수 }\end{array}$ & 측정변수 & 표준入 & C.R & $P$ & $\begin{array}{l}\text { 개념 } \\
\text { 신뢰도 }\end{array}$ & AVE \\
\hline \multirow{3}{*}{ 혁신성향 } & $\mathrm{x} 1$ : 새로운 기능에 즉각적 반응 & .84 & - & - & \multirow{3}{*}{.82} & \multirow{3}{*}{.53} \\
\hline & x2 : 최신정보기술에 대한 호기심 & .80 & 13.39 & $* * *$ & & \\
\hline & x3: 최신제품 사용에 대한 충동 & .67 & 11.26 & $* * *$ & & \\
\hline \multirow{3}{*}{$\begin{array}{l}\text { 사회적 } \\
\text { 영향 }\end{array}$} & $\mathrm{x} 4$ : 타인으로부터 호평을 받기 위한 수단 & .65 & 10.43 & $* * *$ & \multirow{3}{*}{.79} & \multirow{3}{*}{.56} \\
\hline & x5 : 나의 개성표출 수단 & .65 & - & - & & \\
\hline & x6 : 타인과의 관계형성 수단 & .98 & 8.96 & $* * *$ & & \\
\hline \multirow{2}{*}{ 정보품질 } & $\mathrm{x} 8$ : 다양한 정보 서비스 제공 & .69 & 8.96 & $* * *$ & \multirow{2}{*}{.71} & \multirow{2}{*}{.55} \\
\hline & x9 : 최신 정보서비스 제공 & .78 & - & - & & \\
\hline \multirow{2}{*}{ 시스템품질 } & $\mathrm{x} 10$ : 화면 전환속도의 신속성 & .81 & - & - & \multirow{2}{*}{.75} & \multirow{2}{*}{.60} \\
\hline & x11 : 쉽게 이용할 수 있는 정도 & .73 & 11.83 & $* * *$ & & \\
\hline \multirow{2}{*}{$\begin{array}{l}\text { 지각된 } \\
\text { 유용성 }\end{array}$} & $\mathrm{y} 1$ : 획득한 정보가 사용자에게 유용한 정도 & .74 & 12.32 & $* * *$ & \multirow[b]{2}{*}{.78} & \multirow[b]{2}{*}{.64} \\
\hline & $\begin{array}{l}\mathrm{y} 2 \text { : 획득한 정보가 사용자의 업무처리 시간을 절약해 } \\
\text { 주는 정도 }\end{array}$ & .86 & - & - & & \\
\hline \multirow{2}{*}{ 태도 } & y4 : 흥미로움 & .73 & - & - & \multirow{2}{*}{.84} & \multirow{2}{*}{.73} \\
\hline & y5 : 매력적임 & .73 & 14.61 & $* * *$ & & \\
\hline \multirow{2}{*}{ 만족도 } & y7 : 제공된 정보에 대한 만족 정도 & .82 & - & - & \multirow{2}{*}{.79} & \multirow{2}{*}{.65} \\
\hline & y8 : 시스템 기능에 대한 만족 정도 & .79 & 14.01 & $* * *$ & & \\
\hline \multicolumn{7}{|c|}{$\begin{array}{l}\mathrm{X}^{2}=130.190(\mathrm{p}=.016), \mathrm{df}=98, \mathrm{GFI}=.949, \mathrm{AGFI}=.920, \mathrm{NFI}=.945, \mathrm{CFI}=.986, \mathrm{RMR}=.025 \text { RMSEA }=.034, \text { PGFI }=.608, \mathrm{PNFI}=.632 \text {, } \\
\text { PCFI }=.710\end{array}$} \\
\hline
\end{tabular}


「정보시스템연구」제21권 제3호, 2012년 9월

<표 7> 개념변수의 상관계수 및 AVE 제곱근

\begin{tabular}{|c|c|c|c|c|c|c|c|}
\hline 개념변수 & 1 & 2 & 3 & 4 & 5 & 6 & 7 \\
\hline 개인혁신성 & $.728^{*}$ & & & & & & \\
\hline 사회적 영향 & .717 & $.747^{*}$ & & & & & \\
\hline 정보품질 & .452 & .589 & $.841^{*}$ & & & & \\
\hline 시스템품질 & .384 & .447 & .738 & $.774^{*}$ & & & \\
\hline 지각된유용성 & .44 & .526 & .707 & .652 & $.801^{*}$ & & \\
\hline 태도 & .512 & .626 & .501 & .558 & .633 & $.855^{*}$ & \\
\hline 만족도 & .416 & .471 & .548 & .744 & .753 & .684 & $.806^{*}$ \\
\hline
\end{tabular}

*=AVE 의 제곱근

것으로 볼 수 있다.

타당성 검사의 기준 또한 3 가지 검사를 권장 한다(김대업, 2008), 첫째, $\lambda$ 값이 유의해야 하며, 둘째, $\lambda$ 값이 0.7 이상, 셋째, 두 잠재요인의 각 $\mathrm{AVE}$ 가 두 잠재요인의 상관계수의 제곱보다 커 야 한다. <표 6>에서 볼 수 있는 바와 같이, 모든 측정변수의 $\lambda$ 값이 유의하며 0.7 이상이 되는 것 을 볼 수 있다. 또한, <표 7>에서 볼 수 있는 바와 같이, 두 개념변수의 각 AVE는 두 개념변 수의 상관계수의 제곱보다 크기 때문에 측정변 수들의 타당성 역시 확보되었음을 알 수 있으며, 본 논문에서 사용한 측정변수는 경로분석 등 추 가적인 분석을 진행하는데 무리가 없는 것으로
나타났다.

\section{3 가설 검증 및 분석}

4.3.1 사용자 만족도 구조모형에 대한 가설 검증 및 토의

본 절에서는 완료된 확인요인분석모형을 토 대로 가설검증을 위한 경로분석을 실시하였다. 경로모형의 적합도지수는 <표 8>과 같이, 전반 적인 부합지수가 충족되고 있는 것으로 나타났 다. 일반적으로 구조방정식모형의 부합지수로 서, 기초부합지수(Goodness-of-fit index)나, 조 정부합지수(Adjusted goodness-of-fit index), 표

<표 8> 경로분석결과와 가설채택여부

\begin{tabular}{|c|c|c|c|c|c|}
\hline \multicolumn{2}{|r|}{ 가 설 } & $\begin{array}{c}\text { 표준화 } \\
\text { 결로계수 }\end{array}$ & 표준오차 & $\mathrm{p}$ 값 & $\begin{array}{c}\text { 가설채택 } \\
\text { 여부 }\end{array}$ \\
\hline \multirow{2}{*}{ H1 } & H1a :개인혁신성 $\rightarrow$ 유용성 & .088 & .077 & .338 & 기각 \\
\hline & $\mathrm{H1b}:$ 사회적 영향 $\rightarrow$ 유용성 & .230 & .091 & $.035 *$ & 채택 \\
\hline \multirow{2}{*}{$\mathrm{H} 2$} & $\mathrm{H} 2 \mathrm{a}:$ 정보품질 $\rightarrow$ 유용성 & .273 & .126 & $.038^{*}$ & 채택 \\
\hline & $\mathrm{H} 2 \mathrm{~b}:$ 시스템품질 $\rightarrow$ 유용성 & .371 & .119 & $.000 * *$ & 채택 \\
\hline \multicolumn{2}{|c|}{$\mathrm{H} 3$ : 유용성 $\rightarrow$ 태도 } & .795 & .105 & $.000 * *$ & 채택 \\
\hline \multicolumn{2}{|c|}{$\mathrm{H} 4$ : 태도 $\rightarrow$ 만족도 } & .764 & .058 & $.000 * *$ & 채택 \\
\hline \multicolumn{6}{|c|}{$\begin{array}{l}\mathrm{n}=278, \mathrm{x}^{2}=184.271(\mathrm{p}=.000), \mathrm{df}=92, \mathrm{GFI}=.921, \mathrm{AGFI}=.883, \mathrm{NFI}=.915, \mathrm{CFI}=.955, \mathrm{RMR}=.043, \mathrm{RMSEA}=.060 \\
\text { PGFI }=.623\end{array}$} \\
\hline
\end{tabular}

${ }^{*}: \mathrm{p}<.05,{ }^{*}: \mathrm{p}<.01$ 
본부합지수(Normed fit index), 비교부합지수 (Comparative fit index) 등은 모형 수용기준으 로 0.9 이상을 권정하고 있고, 원소 간 평균차이 인 RMR(Root mean square residual)은 0.05 이 하를 제시하고 있다. 절대적합지수중의 하나인 카이스퀘어 $\left(x^{2}\right)$ 값이 권장기준을 완전히 충족시 키지 못한다 할지라도 일부 지수들이 권장수준 내에 있다면 연구모형의 적합성을 수용할 수 있 다.

$<$ 표 8>이 보여주는 바와 같이, 모형설명력을 나타내는 적합지수들인 CFI, GFI, AFGI, NFI, $\mathrm{RMR}$ 등이 권장기준을 충족하고 있으며 AGFI 의 경우도 0.9 에 근접하고 있기 때문에, 본 연구 모형을 검증하기 위해 수집된 데이터는 연구모 형에 적합하다고 볼 수 있다.

<연구가설 H1>은 SNS의 사용자측면의 특성 인 개인혁신성과 사회적 영향이 지각된 유용성 에 유의한 영향을 미치는지 검증하기 위한 것이 다.

분석결과 <표 8>에 나타난 바와 같이, SNS 사용자의 개인혁신성은 지각된 유용성에 유의 한 영향을 미치지 않는 것으로 나타났지만, SNS 사용자의 사회적 영향정도는 유의수준 0.05 에 서 지각된 유용성에 유의한 영향을 미치는 것으 로 나타났다. <세부가설 $\mathrm{H1a}$ >는 기각되었지만, <세부가설 H1b>는 채택되었다. 따라서, SNS의 사용자 측면이 지각된 유용성에 유의한 영향을 미칠 것이라는 가설 $\mathrm{H} 1$ 은 부분채택 되었다. <세 부가설 $1 \mathrm{a}>$ 가 기각된 이유를 유추해 보면, 혁신 적 성향의 SNS 사용자들에게는 SNS가 더 이상 유용한 정보를 획득할 수 있게 하거나 효율적인 업무처리를 가능하게 하는 새로운 서비스로 인 지되지 않기 때문인 것으로 해석할 수 있다. 반
면, <세부가설 $1 \mathrm{~b}$ >는 채택된 것으로 보아, 사회 적 관계를 중시하는 사람일수록 SNS에 대한 유 용성을 크게 느낀다는 것을 알 수 있으며, SNS 가 사회적 관계를 증진시키는 기능을 충실하게 제공할수록 SNS에 대한 유용성을 느끼는 사용 자들이 많아질 것으로 기대할 수 있다. 강재은 (2011)의 연구에서도 비슷한 결과가 도출되었 듯이, 초기에는 $\mathrm{SNS}$ 에 대하여 잘 아는 조기수용 자들(early adopter) 중심으로 사용되었으나, SNS 사용단계가 도입기를 지나 성장 및 성숙기 로 접근하는 상황에서 개인의 혁신적 호기심보 다는 타인과의 관계형성이나 개성표출 수단 또 는 타인으로부터 호평을 받기 위한 수단으로서 SNS가 이용되고 있다고 해석할 수 있다.

<연구가설 $\mathrm{H} 2$ >는 SNS의 시스템 측면인 정 보품질과 시스템품질이 지각된 유용성에 유의 한 영향을 미칠 것인지 검증하기 위한 것이다. <표 8>에 나타난 바와 같이, SNS의 정보품질과 시스템품질은 각각 유의도 0.05 와 0.01 수준에 서 지각된 유용성에 유의한 영향을 미치는 것으 로 나타났다. 따라서, 가설 $\mathrm{H} 2$ 는 채택되었다. 이 러한 결과는 DeLone \& McLean(2003)의 연구 와 일치하는 것으로, 사용자들은 SNS를 통하여 최신의 다양한 정보를 신속하고 편리하게 획득 가능할수록 SNS에 대한 유용성을 지각한다는 것을 알 수 있다. 이에 따라, SNS제공자는 최신 의 다양한 정보를 신속하고 편리하게 제공할 수 있도록 하여야 할 것이다.

<연구가설 H3>은 SNS에 대한 지각된 유용 성이 태도에 유의한 영향을 미치는지 검증하기 위한 것이다. <표 8>에 나타난 바와 같이, SNS 의 지각된 유용성은 유의수준 0.01 에서 지각된 유용성에 유의한 영향을 미치는 것으로 나타났 
다. 따라서, 가설 H3은 채택되었다. <연구가설 $\mathrm{H} 4>$ 는 SNS에 대한 태도가 사용자 만족도에 유 의한 영향을 미치는지 검증하기 위한 것이다. <표 8>에 나타난 바와 같이, SNS에 대한 태도는 유의도 0.01 수준에서 만족도에 유의한 영향을 치는 것으로 나타났다. 따라서, 가설 $\mathrm{H} 4$ 는 채택 되었다. 이러한 결과는 기존 기술수용모형의 결 과와 비슷한 것으로, 본 연구의 가설검증에 대한 다른 부분도 신뢰할 수 있을 것임을 보여주는 대목이라 할 수 있다.

\subsection{2 서비스유형에 대한 조절효과 검증 및 토의}

SNS의 서비스유형을 웹기반 SNS와 모바일 SNS로 구분하고 각 사용자 집단들에 대하여 서 비스유형의 조절효과가 있는지 여부를 살펴보 았다. 구조방정식 모형에서 조절효과의 검증은
조절변수에 따라 집단을 구분하고 집단 간 경로 계수 차이의 유의성 검증(z검증통계량)이 제시 된다. 두 추정모수 간의 $\mathrm{z}$ 검증통계량의 절대값 이 2.58보다 크면 유의수준 $1 \%$ 수준에서, 1.96보 다 크면 유의수준 $5 \%$ 에서 두 추정모수들 간에 차이가 있는 것으로 보며 집단에 따라서 조절효 과가 있는 것으로 판단한다(김주환, 2009).

<연구가설 H5>는 SNS의 사용자 특성요인들 이 지각된 유용성에 미치는 영향은 서비스유형 에 따라 차이를 보일 것인지 검증하는 것이다. $<$ 표 9>에 나타난 바와 같이, SNS 사용자의 개인 혁신성이 지각된 유용성에 미치는 영향은 웹기 반 SNS를 사용하는 집단과 모바일 SNS를 사용 하는 집단 간에 유의수준 0.05 에서 유의한 차이 가 있는 것으로 나타났다. 즉, <세부가설 $\mathrm{H} 5 \mathrm{a}$ > 는 채택되었다. 웹기반 SNS의 경로계수(=.276) 가 모바일 SNS의 경로계수(=-.171)보다 높은

<표 9> 서비스유형에 따른 경로계수 비교

\begin{tabular}{|c|c|c|c|c|c|c|c|c|}
\hline & & 겨 르 & $\begin{array}{l}\text { 웹기본 } \\
\quad(n=\end{array}$ & $\begin{array}{l}\text { SNS } \\
01)\end{array}$ & $\begin{array}{r}\text { 모바 } \\
(n=-10\end{array}$ & $\begin{array}{l}\text { SNS } \\
7)\end{array}$ & CR & 가설 \\
\hline & & 0 오 & 표준경로 & & 표준 & & U.П. & 채택 여부 \\
\hline 사용자 & H5 & $\begin{array}{r}\text { H5a : 개인혁신성 } \rightarrow \\
\text { 지각된 유용성 }\end{array}$ & .276 & .107 & -.171 & .119 & $2.37 *$ & 채택 \\
\hline 즉면 & & $\begin{aligned} \text { H5b : } & \text { 사회적영향 } \rightarrow \\
& \text { 지각된 유용성 }\end{aligned}$ & -.103 & .128 & .564 & .141 & $-3.02 * *$ & 채택 \\
\hline 시스템 & HG & $\begin{aligned} \mathrm{H6a}: & \text { 정보품질 } \rightarrow \\
& \text { 지각된 유용성 }\end{aligned}$ & .424 & .160 & .181 & .232 & 0.83 & 기각 \\
\hline 즉면 & 10 & $\begin{array}{c}\mathrm{H6a}: \text { 시스템품질 } \rightarrow \\
\text { 지각된 유용성 }\end{array}$ & .352 & .127 & .483 & .299 & -0.80 & 기각 \\
\hline H7 & & 지각된 유용성 $\rightarrow$ 태도 & .863 & .118 & .731 & .210 & -0.41 & 기각 \\
\hline H8 & & 태도 $\rightarrow$ 만족도 & .834 & .086 & .738 & .085 & $2.16^{*}$ & 채택 \\
\hline $\begin{array}{l}X^{2}=249 . \\
\text { PGFI }=.5\end{array}$ & $\begin{array}{l}93 \\
57\end{array}$ & $=.000), \quad \mathrm{df}=172, \quad \mathrm{GFI}=$ & $\mathrm{AGFI}=$ & , NFI & 1, CFI & 22, RM & 46, R & $\mathrm{EA}=.04$ \\
\hline
\end{tabular}

$*: p<0.05, * *: p<0.01$ 
것으로 보아, 웹기반 SNS를 이용하는 사용자들 은 모바일 SNS의 사용자들에 비하여 혁신성향 정도가 유용성에 더 많은 영향을 미치고 있음을 알 수 있다. 특히, 웹기반 SNS를 사용하는 그룹 의 개인혁신성은 지각된 유용성에 정(+)의 영향 을 미치고 있지만, 모바일 SNS를 사용하는 그룹 의 개인혁신성은 지각된 유용성에 부(-)의 영향 을 미치고 있다. 이러한 결과는 모바일 SNS를 사용하는 그룹에서는 혁신적인 사람일수록 SNS가 제공하는 정보의 유용성에 대하여 미흡 하게 인식하고 있음을 알 수 있다. 이것을 해석 하면, 모바일 SNS가 제공하는 정보는 혁신자들 이 보기에는 유용성이 미흡한 정보라고 느끼고 있으며, 결국 모바일 SNS는 유용한 정보를 제공 할 수 있는 추가적인 기능들이 필요한 것으로 볼 수 있다.

SNS 사용자의 사회적 영향이 지각된 유용성 에 미치는 영향은 웹기반 SNS를 사용하는 집단 과 모바일 SNS를 사용하는 집단 간에 유의수준 0.01 에서 유의한 차이가 있는 것으로 나타났다. 즉, <세부가설 $\mathrm{H} 5 \mathrm{~b}$ >는 채택되었다. 사회적 영 향과 지각된 유용성 간의 경로계수는 모바일 SNS의 경우(.564)가 웹기반 SNS의 경우(-.103) 보다 높은 것으로 보아, 사회적 영향이 지각된 유용성에 미치는 영향의 강도는 웹기반 SNS보 다 모바일 SNS의 경우가 더 큼을 알 수 있다. 즉, 모바일 SNS가 웹기반 SNS에 비하여 개성 표출을 하거나 타인과의 관계를 증진시킬 수 있 는 기능들을 더 풍부하게 제공하고 있는 것으로 해석할 수 있다. 예를 들면, 시간과 장소에 구애 받지 않고 실시간 주변상황 정보를 모바일 SNS 를 통하여 타인에게 제공할 수 있는 기능은 웹기 반 SNS와 차별화되는 사례라고 할 수 있다. 특
히, 모바일 SNS를 사용하는 그룹의 사회적 영향 은 지각된 유용성에 정(+)의 영향을 미치고 있 지만, 웹기반 SNS를 사용하는 그룹의 사회적 영 향은 지각된 유용성에 부(-)의 영향을 미치고 있 다. 이러한 결과는 웹기반 SNS를 사용하는 그룹 에서 사회적 관계를 중요시하는 사람일수록 $\mathrm{SNS}$ 가 제공하는 정보를 유용하지 않게 느끼고 있음을 알 수 있다. 이것을 해석하면, 웹기반 SNS가 제공하는 정보는 사회적 관계를 중시하 는 사람들이 보기에는 유용성이 미흡한 정보라 고 느끼고 있으며, 결국 웹기반 SNS는 사회적 관계를 증진시키기 위한 유용한 정보를 제공할 수 있는 추가적인 기능들이 필요한 것으로 볼 수 있다. 예를 들면, 블로그 등을 보다 개성있게 표현할 수 있게 한다든가, 블로그 방문자들과의 관계를 유지할 수 있게 하는 등이 그 사례가 될 수 있다.

<연구가설 H6>은 SNS의 시스템 특성요인들 이 사용자의 지각된 유용성에 미치는 영향은 SNS의 서비스유형에 따라 차이를 보일 것인지 검증하는 것이다. <표 9>에 나타난 바와 같이, SNS의 정보품질이 지각된 유용성에 미치는 영 향은 웹기반 SNS를 사용하는 집단과 모바일 $\mathrm{SNS}$ 를 사용하는 집단 간에 유의한 차이가 없는 것으로 나타났다. 즉, <세부가설 $\mathrm{H6a}$ >는 기각 되었다. SNS의 시스템품질이 지각된 유용성에 미치는 영향도 웹기반 SNS를 사용하는 집단과 모바일 SNS를 사용하는 집단 간에 유의한 차이 가 없는 것으로 나타났다. 즉, <세부가설 H6b> 는 기각되었다.

<연구가설 H7>은 지각된 유용성이 사용자의 태도에 미치는 영향은 SNS의 서비스유형에 따 라 차이를 보일 것인지 검증하는 것이다. <표 
「정보시스템연구」 제21권 제3호, 2012년 9월

9>에서 볼 수 있듯이, 지각된 유용성이 태도에 미치는 영향은 서비스유형에 따라 차이를 보이 지 않고 있다. 따라서, <연구가설 H7>은 기각되 었다.

<연구가설 H8>은 SNS에 대한 사용자의 태 도가 만족도에 미치는 영향은 SNS의 서비스유 형에 따라 차이를 보일 것인지 검증하는 것이다. <표 9>에서 볼 수 있듯이, 태도가 만족도에 미치 는 영향은 웹기반 SNS를 사용하는 집단과 모바 일 SNS를 사용하는 집단 간에 유의수준 0.05 에 서 유의한 차이가 있는 것으로 나타났다. 즉, <연구가설 H8>은 채택되었다. 윕기반 SNS에서 의 경로계수(=.834)가 모바일 SNS에서의 경로 계수(=.738)보다 높은 것으로 보아, 태도가 만족 도에 미치는 영향의 강도는 모바일 SNS보다 웹 기반 SNS의 경우가 더 큼을 알 수 있다.

\section{$\mathrm{V}$. 결 론}

SNS는 온라인상에서 불특정 타인과 관계를 맺을 수 있도록 하는 정보시스템 서비스로서, 사 용자들은 SNS를 통해 인맥을 새롭게 쌓거나 기 존 인맥과의 관계를 강화시킬 수 있다. SNS는 우리의 일상생활부터 정치환경까지 다양한 영 역의 변혁을 주도하는 매우 중요한 정보시스템 서비스로서, 그 성장 발전을 촉진하기 위한 다양 한 연구들이 필요하다.

본 논문에서는 정보시스템 성공모형과 기술 수용모형을 토대로 SNS의 사용자특성과 시스 템특성을 외생변수로, 지각된 유용성과 태도를 내생변수로, 사용자 만족도를 종속변수로 설정 한 연구모형과 가설을 제안하였다. 사용자특성
을 나타내기 위한 요인들로는 개인혁신성과 사 회적 영향으로 구성하였고, 시스템특성을 나타 내기 위한 요인들로는 정보품질과 시스템품질 을 설정하였다. 특히, SNS의 서비스유형을 조절 변수로 설정하여 웹기반 SNS인지, 모바일 SNS 인지에 따라 SNS의 사용자 만족도에 영향을 미 치는 결정요인들 사이의 경로계수가 어떻게 달 라지는지 알아보았다. 그 결과, SNS를 개발하거 나 정책기획을 하는데 도움이 될 수 있는 다음과 같은 시사점을 얻을 수 있었다.

첫째, 사회적 관계를 중시하는 사람일수록 SNS가 제공하는 정보에 대한 유용성을 더 크게 느낀다는 것이다. SNS가 사회적 관계를 증진시 키는 기능을 충실하게 제공할수록 SNS에 대한 유용성을 느끼는 사용자들이 많아질 것으로 기 대할 수 있다. 둘째, SNS 사용자들은 SNS를 통 하여 최신의 다양한 정보를 신속하고 편리하게 획득 가능할수록 SNS가 제공하는 정보에 대한 유용성을 높게 지각한다는 것을 알 수 있다. 이 에 따라, SNS제공자는 최신의 다양한 정보를 신 속하고 편리하게 제공할 수 있도록 하여야 할 것이다. 셋째, 모바일 SNS사용자들 중에서 혁신 적인 성향일수록 SNS가 제공하는 정보의 유용 성에 대하여 미흡하게 인식하고 있다. 결국 모바 일 SNS는 유용한 정보를 제공할 수 있는 추가적 인 기능들이 필요한 것으로 볼 수 있다. 모바일 SNS 운영업체는 SNS게임이나 증강현실 기술 등이 적용된 혁신적인 SNS 기능을 통하여 보다 유용한 정보를 제공할 필요가 있다. 넷째, 웹기 반 SNS의 사용자들 중에서 사회적 관계를 중요 시하는 사람일수록 SNS가 제공하는 정보의 유 용성에 대하여 미흡하게 인식하고 있다. 이것은 웹기반 SNS가 사회적 관계를 증진시키기 위한 
기능들을 충분하게 제공하지 않기 때문인 것으 로 해석할 수 있다. 웹기반 SNS 운영업체는 타 인과의 관계형성을 강화시키거나 개성을 표출 할 수 있는 기능들에 대하여 보완 - 확대할 필요 가 있다. 블로그 등을 보다 개성있게 표현할 수 있게 한다든가, 블로그 방문자들과의 관계를 유 지할 수 있게 하는 등이 그 예가 될 수 있다.

본 연구에서 사용된 표본은 서울·경기, 제주 지역에 집중된 측면이 있고 이는 본 연구의 한계 점으로 지적될 수 있다. 또한, SNS의 사용자특 성과 시스템특성요인들을 더 다양화하거나 세 분화하여 더 구체적인 시사점이 도출될 수 있도 록 하는 추가적인 연구가 필요하다. 또한, 웹기 반 SNS와 모바일 SNS의 집단을 구분하여 조절 효과 분석을 할 때 모바일 SNS에 대한 표본수가 상대적으로 적은 부분도 본 연구의 한계점임을 밝혀둔다.

\section{참고문헌}

고상민, 황보환, 지용구, “소셜 네트워크 서비스 와 온라인 사회적 자본 : 한국과 중국 사례를 중심으로," 한국전자거래학회 지, 제15권, 제1호, 2010, pp.103-118.

가명호, 정대율, “소셜네트워킹 사이트의 e-고객 충성도에 관한 실증연구,” 정보시스템 연구, 제19권, 제2호, 2010, pp.1-21.

강재은, “운영체제에 따른 스마트폰의 지속적 사용 결정요인 비교연구,” 제주대학교 박사학위논문, 2011.

김경남, 박지혜, 정도범, “스마트폰의 특성이 개 인의 업무성과에 미치는 영향과 혁신저
항성의 조절효과,” 정보시스템연구, 제 20권, 제2호, 2011, pp.57-80.

김근형, 윤상훈, "SNS 사용자만족도의 영향요 인 도출 및 서비스형태 별 비교분석,” 인 터넷전자상거래연구, 제 12 권, 제 1 호, 2012, pp.125-143.

김대업, $\mathrm{AMOS} \mathrm{A}$ to $\mathrm{Z}$ 구조방정식 모형분석, 학현사, 2008.

김상현, "RFID기술 수용과 구현에 영향을 주는 요인과 조직 준비성의 조절효과,” 정보 시스템연구, 제19권, 제1호, 2010, pp.149-177.

김상현, 박현선, 김근아, “소셜커머스 특징과 개 인특징이 신뢰와 신뢰성과에 미치는 영 향에 관한 실증연구,” 경영연구, 제26권, 제3호, 2011, pp.95-121.

김주환, 김민규, 구조방정식 모형으로 논문쓰기, 커뮤니케이션북스, 2009.

김해봉, “스마트폰 기반의 모바일 SNS 사례연 구,” 한림대학교 석사학위논문, 2011.

내가영, "모바일 SNS 이용자들의 이용동기와 만족감에 대한 연구,” 서강대학교 석사 학위논문, 2010.

박지홍, "사회네트워킹 사이트 이용자 지속의도 에 영향을 미치는 요인에 관한 탐구,” 정 보관리학회지, 제 25 권, 제 4 호, 2008 , pp.205-226.

서우종, 원욱연, 홍진원, "SNS 웹사이트의 품질 요인이 사용자만족, 지속적 사용의도 및 구전의도에 미치는 영향에 대한 실증연 구,” 한국경영정보학회 춘계학술대회, 2009, pp.823-830.

신호경, 신지명, 이호, “소셜네트워크서비스에 
서의 정보공유에 미치는 영향요인에 관 한 연구,” 정보관리연구, 제42권, 제 1 호, 2011, pp.137-158.

유진, “모바일 SNS 이용의도에 영향을 미치는 요인에 관한 연구,” 충남대학교 석사학 위논문, 2011.

정대율, 민하오자, “소셜 네트워킹 사이트의 이 용과 재방문에 관한 실증적 연구,” 인터 넷전자상거래연구, 제 10 권, 제4호, 2010, pp.193-219.

제일기획, 대한민국 소비자의 SNS 이용형태 조 사, 커뮤니케이션연구소 보고서, 2010. 차상민, “소셜네트워크 서비스의 특성이 몰입에 미치는 영향에 관한 연구,” 국민대학교 석사학위논문, 2011.

한국인터넷진흥원, 인터넷 이용실태조사, 2010. 허성국, “기업의 블로그 사용에 관한 연구:기술 수용모형 관점에서,” 단국대학교 석사 학위논문, 2008.

SK커뮤니케이션즈, “싸이월드, 총 일촌건수 10 억건 돌파,” SK컴즈보도자료, 2010.

Ajzen, I., Attitude Structure and Behavior Relations, in Attitude Structure and Function, Berckler, S.T. and Greenwald, A.G.,(Eds.), Erlbaum, Hillsdale, NJ, 1988.

Arbuckle, J. L., Amos 7.0 User's Guide, Chicago:SPSS, 2006.

Davis, F. D. , "Perceived Usefulness, Perceived Ease of Use, and User Acceptance of Information Technology," MIS Quarterly, Vol.13, No.3, 1989, pp.319-340.

DeLone, W. H., and McLean, E. R., "Information
System Success: The Quest for the Dependent Variable," Information Systems Research, Vol.3, No.1, 1992, pp.60-95.

DeLone, W., and McLean, E, R., "The DeLone and Mclean Model of Information System: A Teb-Year update," Joural of Management Informations Systems, Vol.19, No.4, 2003, pp.3-30.

De Wulf, K. N., Schillewaert, S. M., and Rangarajan, D., "The Role of Pleasure in Web Site Success," Information and Management, Vol.43, No.4, 2006, pp.434-446.

Gatian, A. W., "IS User Satisfaction a Valid Measure of Systems Effectiveness?," Information and Management, Vol.26, No.3, 1994, pp.119-131.

McKinny, V., and Yoon, K., "The Measurement of Web-Customer Satisfaction: An Expection and Disconfirmation Approach," Information Systems Research, Vol.13, No.3, 2002, pp.296-315.

Ohbyung, K., and Yixing, W., "An Empirical Study of the Factors Affecting Social Network Service Use," Journal of Computers in Human Behavior, Vol.26, Issue 2, 2010, pp.254-263.

Olusegun, F., Rebecca, O. V., Adebayo, F. A., and Adewale, O. O., "Diffusion of Innovation in Socila Networking Sites among University Students," International Journal of Computer 
Science and Security(IJCSS), Vol.4, Issue 3, 2010, pp.361-372.

Rogers, E. M., Diffusion of Innovation, 4th edition, Free Press, New York, 1995.

Seddon, P, B., "A Respecification and Extension of the Delone and Mclean Model of IS Success," Information System Research, Vol.8, No.3, 1997, pp.240-253.

Venkatesh, V., and Davis, F. D., "A Theoretical Extension of the Technology Acceptance Model: Four Longitudinal Field Studies," Management Science, Vol.46, No.2, 2000, pp.186-204.

Facebook, Statistics, http:// facebook.com, 2011.

Smith, G., Social Software Building Blocks, http://nform.ca/ publications, 2007.

Twitter, Twitter Status,

https://business.twitter.com,2011,

\section{윤상훈(Yun, Sang-Hun)}

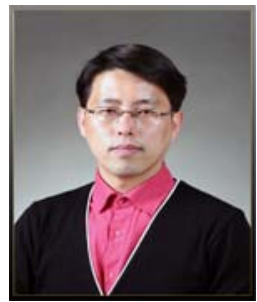

니스 등이다.
영동대학교 시각디자인학 과에서 학사를 받았으며, 제주 대학교 경영정보학과에서 석 사학위를 받았다. 현재, (재)제 주테크노파크IT·SW부 전임연 구원으로 재직 중이다. 주요관 심분야는 정보시스템, e-비즈

\section{김근형(Kim, Keun-Hyung)}

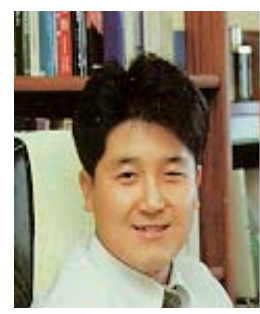

서강대학교 컴퓨터학과에 서 학사, 석사, 박사학위를 받 았다. 현재, 제주대학교 경영 정보학과 교수로 재직 중이다. 주요관심분야는 정보시스템, 데이터마이닝 등이다.

\section{오성렬(Oh, Sung-Ryoel)}

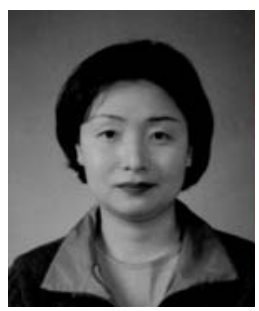

제주대학교 회계학과에서 학사를 받았으며, 한양대 대학 원 회계학과에서 석사 및 박사 학위를 받았다.

현재, 제주국제대학교 경영. 세무학과 부교수로 재직 중이 다. 주요관심분야는 세무회계, 회계정보, 연구방법론 등이다. 
$<$ Abstract $>$

\title{
Structure Modeling on Factors Influencing the User Satisfaction of Social Network Services by Mediating the Moderator of the Service Types in SNS
}

\author{
Yun, Sang-Hun $\cdot$ Kim, Keun-Hyung $\cdot$ Oh, Sung-Ryoel
}

The first purpose of this paper is to identify factors having an effect on the user satisfaction of the SNS(Social Network Services) users and to examine causal relationships among those factors. The second is to examine how the causal relationships between the factors could be changed in the service types in SNS, which would be divided into web based SNS and mobile SNS. For achieving the purposes, we established the research model and hypotheses based on Information Success and Technology Acceptance Model. The characteristics of the SNS users consist of Individual Innovation and Social Influence while the characteristics of the SNS system consist of Information Quality and System Quality. The hypotheses were verified by analyzing data, which was collected from survey research on users of the SNS, with AMOS 18.0 statistical package. As a result, the first, we observed that more important the SNS users would consider the social relation, more useful they would recognize the function of SNS. The second, we observed that faster and easier the users could obtain hourly information in diversity, more useful they would recognize the function of SNS. The third, we observed that more innovative the mobile SNS users would become, more negative they would consider the usefulness of SNS. The fourth, we observed that more important the web based SNS users would consider the social relation, more negative they would consider the usefulness of SNS.

Key words : SNS(Social Network Service), Individual Innovation, Social Influence, Information Quality, System Quality, Service Types, Web Based SNS, Mobile SNS.

\footnotetext{
* 이 논문은 2012년 2월 1일 접수되어 1차수정(2012년 5월 1일)과 2차수정(2012년 5월 22일), 3차수 정(2012년 5월 29일)을 거쳐 2012년 7월 2일 게재 확정되었습니다.
} 